\title{
A KATASZTRÓFAVÉDELEM KOMPLEX FELADATRENDSZERE FÖLD ALATTI GÁZTÁROLÓ ÜZEMEK ESETÉN
}

\section{THE DISASTER MANAGEMENT'S COMPLEX DUTY SYSTEM IN CASES OF UN- DERGROUND GAS STORAGE PLANTS}

\author{
ENDRÖDI István; TÓTH András \\ (ORCID ID:0000-0002-3376-1389); (ORCID ID:0000-0002-7365-6620) \\ endrodi.istvan@uni-nke.hu; andras.toth@katved.gov.hu;
}

\begin{abstract}
Absztrakt
A szénhidrogén raktározás egy speciális területét, a földalatti gáztárolást mutatják be a szerzők, a katasztrófavédelem önkormányzati és rendvédelmi feladatainak szemszögéböl vizsgálva. A szénhidrogénekben lévö szénatomok kapcsolódása végtelen számú variánst hozhat létre, amelyek közül a gázhalmazállapotban lévő földgáz tulajdonságait, keletkezésének, szállitásának és tárolásának módját ismertetik. Egy magyarországi földalatti gáztárolón keresztül bemutatják a katasztrófavédelem feladatait a veszélyeztető hatások elkerülése, kezelése érdekében. Szerzők megvizsgálnak egy gáztárolót érintő tűzesetet, hatásait és a lakosság tájékoztatásának lehetőségeit. Vizsgálják a vonatkozó törvények és rendeletek irányadó részeit. Céljuk, az üzemeltetés biztonságosabbá tétele, a lakosság megóvása, felkészítése a gáztárolást érintő különleges helyzetekre.
\end{abstract}

Kulcsszavak:földgáztárolás, lakosságvédelem katasztrófavédelem, infokommunikáció

\begin{abstract}
The authors are going to exhibit underground gas storage that is a special field of hydrocarbon storage from the viewpoints of council and safety duties of the disaster management. The bonds between carbon atoms in hydrocarbons can form an infinite number of variants which they are going to describe the qualities of and also explain the methods for producing, transporting, and storing the gaseous natural gas. Using a Hungarian underground gas storage as an example they are going to demonstrate the duties of disaster management that are necessary for avoiding or handling endangering effects. They will examine a case of fire in a gas storage, its effects and the possible ways of informing the population. They are going to investigate the main parts of related laws and decrees. Their goal is to make the operations safer, protecting the population and also preparing it for unique situations connected to gas storage.
\end{abstract}

Keywords: natural gas storage, disaster management, protection of the population, infocommunication 


\section{BEVEZETÉS}

A lakosság felkészítése a különleges helyzetekre az adott veszélyes ipari üzem és a katasztrófavédelem egyik legfontosabb közös feladata. Az élet eddig is igazolta az előrelátó, minden eshetőségre felkészült üzemeket, akik a tervszerü karbantartásokkal a minimálisra csökkentik a meghibásodások számát, valamint jól felkészült menedzsment végzi a lakosság tájékoztatását.

Magyarország iparának egy része elavult, a gyáregységek átlagéletkora magas. Az eseti meghibásodások elhárításán felüli technológiai berendezések cseréjére az „új” tulajdonosok nem költenek, minél nagyobb hasznot próbálnak kisajtolni az adott üzemegységből.

A jogszabályváltozások 2012-től megkövetelik minden magyarországi veszélyes üzem irányítójától a környezet és lakosság védelmét. [1] A törvényhozó a jog eszközét adta a katasztrófavédelem kezébe, hogy a környezetet önkormányzati és rendvédelmi kellékekkel megvédje.

Speciális területet vizsgálnak a szerzők, a szénhidrogén-felhasználáshoz kapcsolódó földalatti gáztárolást. Hazánk importfüggősége a gázfogyasztás tekintetében magas. A termelt és importált földgáz a hazai felhasználást elégíti ki. A gázszolgáltatótól érkező földgáz részben közvetlenül a háztartásokba és intézményekhez kerül, részben pedig a szezonális igényeket kielégítő erőmüvekben használják fel. A szezonális igények kielégítésében a gáztárolók meghatározó szerephez jutottak az elmúlt két évtizedben. A gázfogyasztás a korábbi évek enyhe emelkedését követően stagnált, a hazai termelés súlya a forrásokat tekintve drasztikusan csökkent. A téli gázigényeket döntően a hazai gáztárolókból elégítettük ki. A kissé növekvő tendenciát mutató ukrajnai bértárolás elsősorban gazdaságossági okokkal magyarázható.

A gáztárolók kihasználtsága a gázfogyasztás stagnálásával enyhén csökken. Ebben szerepet játszik az alternatív energiák terjedése a háztartásokban:

- napkollektorok és napelemek,

- az építési kultúra változásai, (könnyüszerkezetes és passzívházak)

- jogszabályváltozások,

- az állami támogatások növekedése. (homlokzati, födémszigetelések)

A hazai olaj és földgázipar bölcsőjét tekintve a szénhidrogén kutatások kiszélesítésével fedezték fel a Pusztaederics mellett feltárt gázcsapadék mezőt 1946-ban. A nyugat-dunántúli gáztermelés kiemelt fontosságú volt, mivel az itt termelt földgázzal látták el a nyugati országrészt összekapcsolt szállítóhálózat hiányában. A gáztermelést 1951-ben kezdték meg.

A 2000-es éveket követően több nagyvolumenü rekonstrukciós munka keretében fejlesztették a tárolót kútoldali és felszín technológiai vonatkozásban egyaránt. A kutak kúttalpi áteresztőképességének javítását végezték el, továbbá a teljes glikolregeneráló ${ }^{1}$ technológia korszerüsítésen esett át 2002-2003-ban, illetve a gázüzemi gázelőkészítő technológia élettartam növelési projekt keretében került felújításra. A kompresszorok gépészeti felújítása is előtérbe került a 2000-es évek elején, majd ezt követően a gépeket vezérlő irányítástechnikai rendszer megvalósítása, és ennek köszönhetően a teljesítmény szabályzó rendszer kiépítésével érhették el a hatékony üzemvitelt. A tárolóban levő egyes technológiai elemek közel negyven éves múltra tekintenek vissza, így a folyamatirányító rendszer korszerüsítése megalapozta a biztonságos rendszer felügyeletet. [2]

\footnotetext{
${ }^{1}$ A földgázszárítás első lépése a glikolos érintkeztetés. A (mono-, di-, vagy trietilén-) glikol érintkezve a nyers földgázzal, felveszi annak víztartalmának nagy részét. Az érintkeztetőbe bemenő közegek tehát a nyers földgáz és a tömény glikol, a kijövők a száraz földgáz és a híg glikol. A kijövő híg glikolt forralással regenerálják. A regeneráló páracsövén keresztül távozó gőz egy része kondenzálódik, és ezt kondenzátumként összegyüjtik. A maradék gőz az atmoszférába kerül.
} 
Tárolói sajátosság, hogy az országban található tárolók közül a Pusztaedericsi az egyetlen tároló ahol szagosított földgázt forgalmaznak, így a gázkifújás észlelésének valószínüsége nagyobb, mint más tárolókban. A kiépítés alatt lévő biztonsági rendszer 8 másodperc alatt leállítja a gáz ki- és belépési pontjait, $\mathrm{s}$ a technológiai rendszerben maradt gázt fáklyán elégeti.

A legnagyobb odafigyelés - folyamatos karbantartás, felügyelet - ellenére is történhet baleset, amely során nem mindig az emberi tényező dominál. A hatalmas, közel 100 bar üzemnyomású tolózár anyaghibája vezethetett a Nagyhegyesi (Hajdúszoboszlói) földalatti gáztárolót érintő tüzesethez, melynek kapcsán megvizsgálom a lakosságtájékoztatás hatékonyságát.

\section{A FÖLDGÁZ KIALAKULÁSA}

A földgáz évmilliók során, a föld alatt és a tengerek mélyén szerves anyagok bomlási termékeként keletkezett. A felszín alatt, a kőzetek repedésein keresztül fedőkőzetek által határolt mezőkbe vándorolt.

A földfelszín alatt néhány métertől több mint 5000 méteres mélységig található. Rendszerint akkor képes a felszínre törni, ha a talaj laza, de ha a migráció akadályba ütközik, az üledékes tároló kőzetben létrejött csapdában reked. A szénhidrogének száma végtelen, amit jellemzően a földgázból és a kőolajból származtatunk. [3]

Két nagy csoportja a telített és a telítetlen szénhidrogének. ${ }^{2}$ A telítetlen egyszeres, míg a telített szénhidrogének atomjai két-háromszoros kovalens kötéssel kapcsolódnak egymáshoz.

A földgáz négy gázhalmazállapotú gáz keveréke: metán, etán, propán, bután. Földgáz alatt azonban olyan gázkeveréket értenek, amelyek túlnyomóan metánból $\left(\mathrm{CH}_{4}\right.$, rövidítése $\left.\mathrm{C} 1\right)$ a pentánig $\left(\mathrm{C}_{5} \mathrm{H}_{10}\right.$, rövidítése $\left.\mathrm{C}_{5}\right)$ terjedő egyszerü parafinokból állnak. Színtelen, vízben nem oldódó gáz. Éghető, robbanásveszélyes, széndioxiddá és vízzé ég el.

Még nem bizonyított, hogy a szapropélből ${ }^{3}$ keletkezett-e a földgáz, - csak eltérő módon, mint a kőolaj - vagy pedig a kőolaj lebomlásából származik. A földgáz leleteknek mintegy egyharmada a kőolajjal együtt található. [4]

\section{A földgáz termelése}

A gyakran alkalmazott rotary fúrás ${ }^{4}$ során a fúrófejet acélcső-kötegekhez rögzítve hajtják a kőzetbe, és a felszínen, a fúrótornyon elhelyezkedő úgynevezett forgóasztal gondoskodik a fej meghajtásáról. A fúráspont fölött elhelyezkedő fúrótorony mind újabb acélcsövek csatlakoztatását teszi lehetővé a fúrás elörehaladtával.

A fúrófej által kimart kőzetet - az úgynevezett omladékot - a fúrórudazattal együtt bevezetett öblítőfolyadékkal hozzák fel a felszínre a kőzet és a rudazat közötti résen. Ezzel a módszerrel közel 10000 méteres mélységig lehet lefúrni.

\footnotetext{
${ }^{2}$ A szénhidrogének között megkülönböztetnek telített és telítetlen szénhidrogéneket az alapján, hogy a szénatomok között csak egyszeres kötések találhatók, vagy a molekulák tartalmaznak két- vagy háromszoros kötéseket is. A telített szénhidrogénekben a szénatomok vegyértékének megfelelő maximális számú hidrogénatom található. A szénatomok csak egyszeres kötésekkel kapcsolódnak össze bennük. Az alkánok (vagy paraffinok) nyílt láncú telített szénhidrogének. Alkánok például a metán a legegyszerübb alkán a propán.

3 A lebegő életmódot folytató élőlények elhalásuk után, a fenékre halmozódnak fel és a kénhidrogént termelő baktériumok miatt, a szerves anyag nem oxidálódik, hanem rothadó iszap, szapropél halmozódik fel. A szerves anyag felhalmozódása oxigénszegény környezetben történhet. Ilyen feltételek kialakulhatnak beltengerekben vagy elzárt lagúnákban. A szerves anyag további betemetődéssel sötétszürke bitumenes kőzetté, a kőolaj és földgáz anyakőzetévé alakul.

${ }^{4}$ A nagyobb mélységü fúrások esetében a leggyakrabban alkalmazott technika az un. rotary fúrás, amelynél a fúrószár végén a forgó mozgást végző görgős fúrófej (bit) zúzza össze a kőzeteket. A törmeléket (cuttings) általában a száron keresztül érkező speciális összetételü fúróiszap (drilling mud) szállítja a felszínre a száron kívüli un. gyürüstérben.
} 
Egy másik megoldási lehetőséget kínál az úgynevezett talpi fúrómotor: ez egy közvetlenül a fúrófej fölött elhelyezkedő, az öblítőfolyadék nyomása által hidraulikusan meghajtott motor. Ezt a módszert elsősorban ferde fúrásoknál alkalmazzák.

Mivel a fúrónak különböző keménységü kőzetekkel kell megbirkóznia, különböző kőzettípusokra kifejlesztett fúrófejek léteznek. A fúrófej cseréje - amelyet a kopás is indokolhat - különösen a mély fúrásoknál meglehetősen hosszadalmas művelet, hiszen a teljes fúrórudazatot ki kell emelni.

A kitermelés kezdetén a telepen belül többnyire magasnyomás uralkodik. Minél mélyebben található a lelőhely, annál nagyobb a nyomás: 10 méterenként átlagosan 1 bar-ral növekszik. A telepben uralkodó természetes rétegnyomás révén a földgáz magától tör a felszínre. Ezt elsődleges kitermelésnek nevezik. A kitermelés előrehaladtával a telepben uralkodó nyomás csökken.

\section{A földgáz szállítása}

Ha a természetes nyomás már nem elegendő ahhoz, hogy a gáz végighaladjon a szállítóvezetékeken (1. ábra), akkor a felszínen kompresszorokat telepítenek a szállításához. [5]

A száraz kutakból a gáz 60-80 \%-át a saját nyomása a felszínre hajtja. A földgázt a mezők közelében, földgázüzemekben tisztítják és előkészítik szállításra. A szállítás túlnyomó többségben csővezetékeken történik, a teljes magyar gázhálózat hossza 450000 kilométer. Cseppfolyósítással is szállítható, 100000 tonna feletti hajókkal $-161 \mathrm{C}^{\circ}$ alatt.

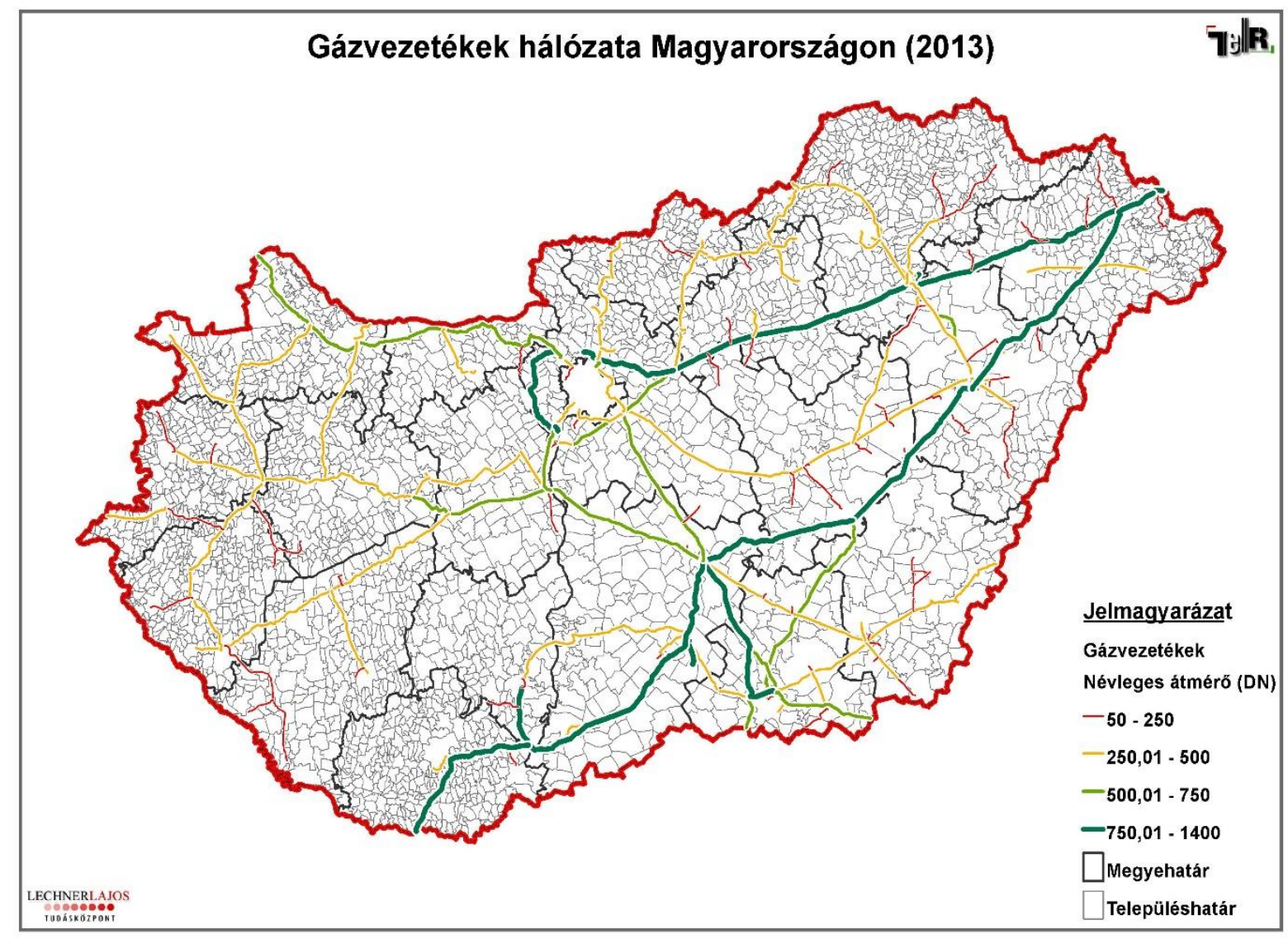

1. ábra Magyarországi gázvezetékek hálózata [6] 


\section{A Földgáz tárolása}

A földgáz földalatti gáztárolókban (2. ábra) vagy cseppfolyósítással tárolható.

Az öt magyar földgáztároló létesítmény porózus geológiai szerkezetü. Jellemzően homokkő kőzetben tárolják a földgázt, ez alól kivételt képez a mészhomokkő alapú zsanai tároló. [7]

Ezeket a geológiai képződményeket - amelyekből a földgáz kitermelése részben vagy teljesen befejeződött és bizonyítást nyert, hogy földgáz tárolására alkalmasak - átalakították földalatti gáztárolókká. Az átalakítás kiterjedt:

- az eredetileg gázkitermelés céljából használt kutak átalakítására, szükség szerint újak fúrására;

- a földgázt gyüjtő-elosztó rendszer kiépítésére;

- az ehhez kapcsolódó betárolási és gázelőkészítő berendezések telepítésére;

- a megfelelö távvezetéki kapcsolatok kiépítésére.

Földgáztárolási célra kizárólag az a földgázt tároló réteg jöhet számításba:

- amelyiknek a zártsága bizonyított a későbbi tároló üzemeltetéshez,

- ahol maga a tároló kőzet rendelkezik a szükséges tárolási tulajdonságokkal, és emellett kellőképpen állékony,

- ahova a földgáz viszonylag könnyen besajtolható, tárolható, és a tároló rétegből gazdaságosan, maradéktalanul visszanyerhető.

Száz lemüvelt mezőnek csak a töredéke tesz eleget ezeknek az elvárásoknak. Természetesen a tárolási hely kiválasztásában a müszaki megfontolások mellett gazdaságossági számítások is szerepet játszanak. Alapvető elvárás például, hogy a földgáz viszonylag alacsony, 60-80 bar, legfeljebb 210 bar nyomással besajtolható legyen. Ez akkor teljesül, ha a telep nincs mélyebben, mint 2000-2500 méter, tároló kőzetének pedig jó az áteresztőképessége.
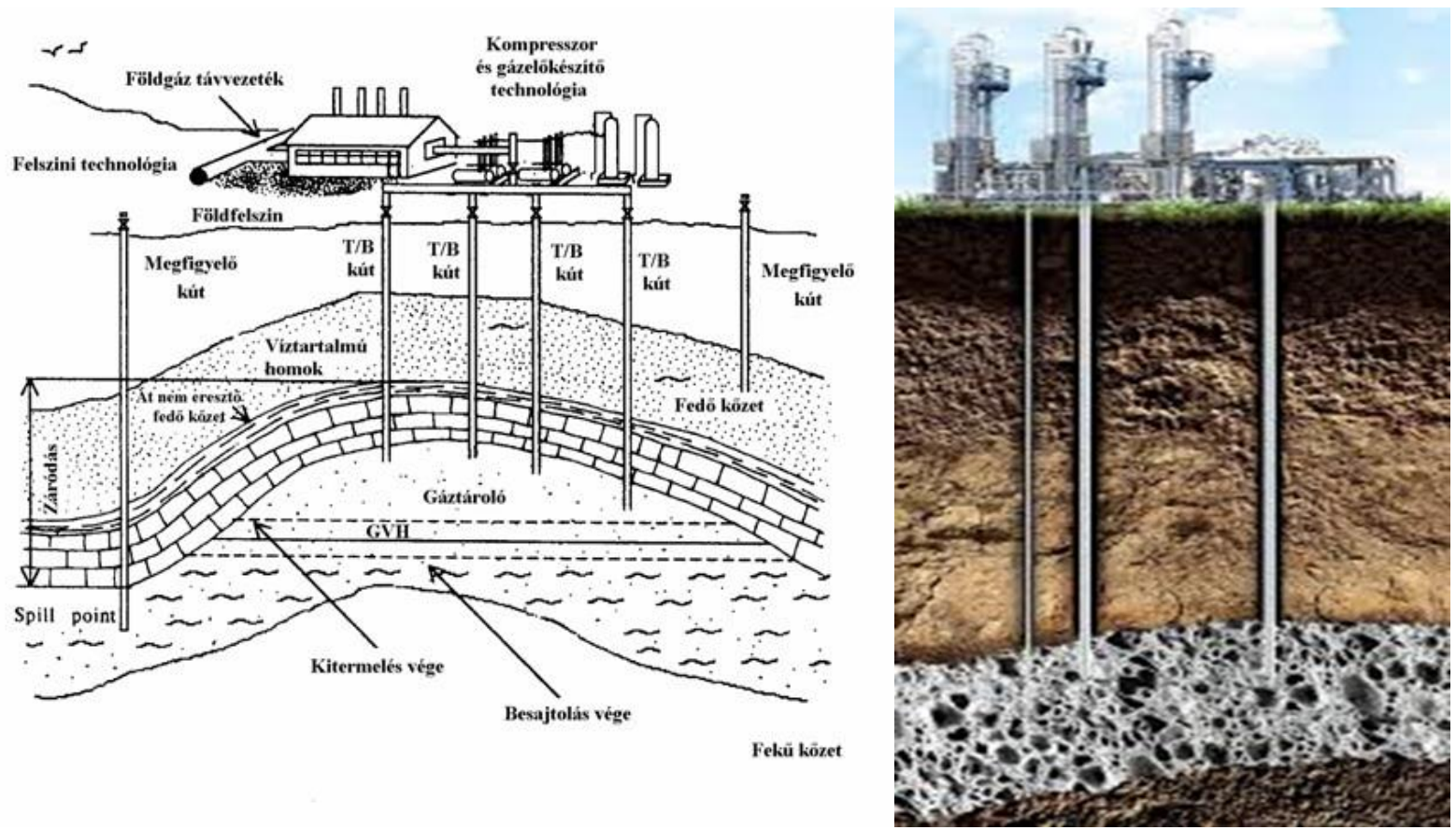

2. ábra Föld alatti gáztárolók szerkezete $[8,9]$

A Gas Infrastructure Europe adatai szerint 15 európai ország rendelkezik földgáztároló kapacitással. Az európai országok közül Magyarország a negyedik legnagyobb gáztároló 
kapacitással rendelkező állam, csupán a német, az olasz és a francia létesítményekben fér el több fütőanyag. (3. ábra)

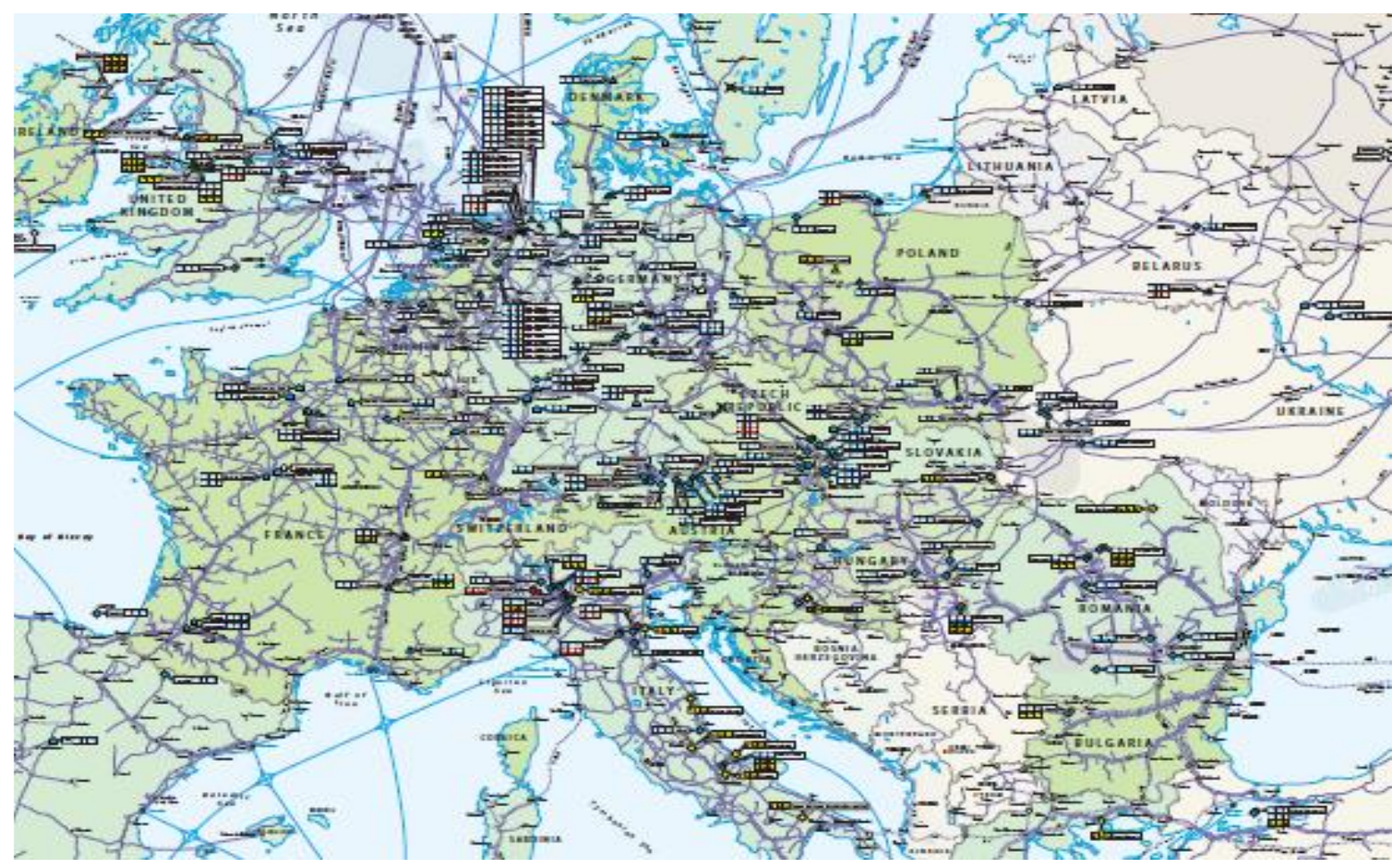

3. ábra Az Európai és Ázsiai földalatti gáztárolók [10]

A régióban Ausztria rendelkezik a legnagyobb kapacitással. A térségben kétmilliárd köbméternél nagyobb befogadóképességü tárolói vannak Lengyelországnak és Szlovákiának.

Az Unió tagállamainak egészében a tárolók kapacitása majdnem eléri a 83 milliárd köbméter gázt. [11] A Magyar Földgáztároló Zrt. (továbbiakban MFGT Zrt.) négy - Zsana, Hajdúszoboszló, Kardoskút, Pusztaederics - gáztárolót üzemeltet. Az MMBF szőregi tárolója kereskedelmi tároló, melynek kapacitásából 915 millió köbméter stratégiai készletnek számít. (4. ábra) 


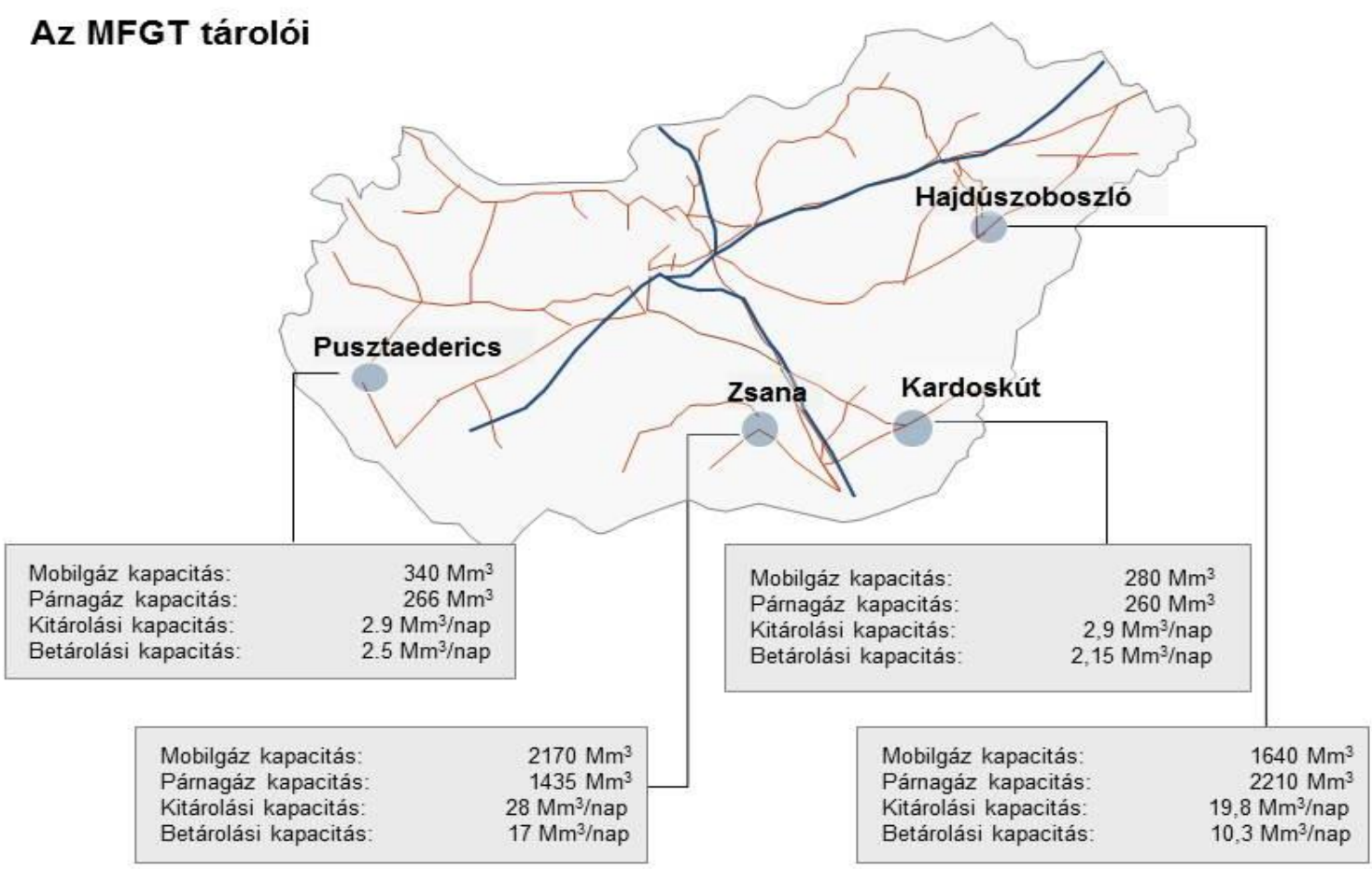

4. ábra A magyarországi földalatti gáztárolók [12]

\section{A PUSZTAEDERICSI FÖLGÁZTÁROLÓ}

A pusztaedericsi gáztároló alsó pannon korú homokkőben (felső és alsó nova telepek, Szolnoki Homokkő Formáció) működik. A tároló a korábbi „hahót-edericsi” letermelt földgázmező hasznosítása révén jött létre. A tároló kialakításának gondolata a hetvenes években vetődött fel, miután a primer termelés befejeződött.

A negyven év alatt a tároló folyamatos fejlesztésen esett át. 1972 és 1991 között három ütemben történt a tároló fejlesztése. Az első ütemben - 1972-79 közötti időszakban - már öt korábbi földgázkitermelő kutat elkezdtek gáztárolásra használni, ezzel a Pusztaedericsi létesítmény hazánk első földgáztárolója volt. A második (1987-89) és harmadik (1989-1991) ütem fejlesztéseivel kialakult a tároló teljes kútállománya és felszíntechnológiai rendszere.

A kezdeti 100 millió köbméteres mobilgáz kapacitás a fejlesztéseknek köszönhetően elérte a 340 millió köbmétert, amely jelenleg is a tároló névleges mobilgáz kapacitása. Természetesen ehhez társul egy 266 millió köbméteres párnagáz készlet, mely a tároló zavartalan müködését biztosítja. A napi kitárolási kapacitások is növekedtek a fejlesztési ütemekkel együtt, így a kezdeti 1,2 millió köbméter napi kitárolási kapacitás 2,9 millió köbméterre emelkedett.

A betárolási napi csúcskapacitás pedig jelenleg 2,9 millió köbméter. Fontos megjegyezni, hogy a pusztaedericsi létesítmény a Dunántúl egyetlen földgáztárolója, ezzel fontos szerepet játszik az ország nyugati részében a nagynyomású vezetékrendszer hidraulikai egyensúlyának fenntartásában. [13] İgy a fejlesztések a három fö ütemmel nem álltak meg, csak a tároló kialakulását tekintve ezt a három fö ütemet tekinthetjük a tároló életében mérföldköveknek.

A tároló üzemeltetése során az elöírt gyártói nagyrevíziók, felülvizsgálatok folyamatosan elvégzésre kerülnek. A technológia állapotát rekonstrukciós fejlesztésekkel és állandó karbantartással tartják fenn. Erre remek példa a 2018-ban és 2019-ben ütemezetten megvalósuló gázelőkészítő berendezések részét képező gáz-gáz hőcserélők cseréje, mellyel a szigorodó gázminőségi elvárásoknak próbálnak megfelelni.

A folyamatos fejlesztések mellett nagy hangsúlyt fektetnek a biztonság tudatosságra és környezetvédelemre. Ennek megfelelően a személyzetet az elöírások szerint oktatják, 
veszélyhelyzetre való felkészítést gyakoroltatják (belsővédelmi tervgyakorlat, tűzoltási gyakorlat stb.).

\section{A betárolt anyagok tulajdonságai}

Az MFGT Zrt. Pusztaederics Földalatti Gáztároló telephelyén leginkább tüzveszélyes anyagok kerülnek betárolásra, de megtalálhatóak környezetre veszélyes anyagok is.

1. Földgáz

A gáztárolóban, illetve a technológiában is nagy mennyiségben kerül tárolásra, illetve felhasználásra. A kikerülő anyagot belélegezve maradandó egészségkárosító hatással nem számolhatunk. Az anyag bódító hatású, szédülést és eszméletvesztést okozhat. Fizikai tulajdonságai miatt vízi környezetben sem akut, sem krónikus hatást nem okoz.

2. CH kondenzátum

A technológiában keletkező anyag, a szeparátorokban történik a leválasztása, majd onnan az üzemi tárolókba kerül. A kikerülő anyag nem mérgező, de bódító hatású, szédülést, hányást, megváltozott tudatállapotot és eszméletvesztést okozhat nagy koncentrációban. Lenyelés esetén megváltozott tudatállapot és eszméletvesztés is tapasztalható akár, bőrrel való érintkezés esetén bőrpír, daganat, vörösödés jelentkezhet. Gőzei a szem irritációját okozhatják. Fizikai tulajdonságai miatt gyorsan elpárolog a vízi környezetből, így sem akut, sem krónikus hatást nem okoz.

3. Metanol $^{5}$

Adalékanyagként használják a technológiában. Tartályban történik a tárolása. Tüzveszélyes és toxikus tulajdonsággal is rendelkezik. A gőze irritálja a szemet és a légzőrendszert. Hatással lehet a központi idegrendszerre, gyomorra, vesére és májra, okozhat tartós vagy ismétlődő fejfájást és látáskárosodást. Éghető, gőzei a levegőnél nehezebbek. Szobahőmérsékleten levegővel robbanóelegyet képez. Lenyelve toxikus. Felszívódása esetén: hányinger, hányás, fejfájás, szédülés, részegség, látászavarok, vakság (a szemideg irreverzibilis károsodása) léphet fel. Vízi szervezeteket károsíthatja.

\section{A természeti környezet súlyos balesetből adódó veszélyeztetettsége}

A vizsgált üzemben nem azonosítottunk olyan eseményt, amely során toxikus anyagok kikerülésére lehetne számítani.

A kutak kitörésekor a kiáramló gázzal együtt a tároló rétegben lévő folyadék egy része is a felszínre kerül. A kikerülö folyadék víz és könnyü szénhidrogének keveréke. A kihordott folyadék mennyisége csekély.

Egy esetleges kútkitörés kapcsán a kitörés közvetlen környezetében a talaj és a talajvíz elszennyeződése várható. A szennyeződés várható mértéke csekély. A kialakuló szennyeződés semmiképpen nem járhat maradandó következményekkel sem az emberekre, sem a magasabbrendủ állatokra nézve.

Az MFGT Zrt. részéröl több feltétel is biztosított, hogy a környezetre káros anyag ne okozzon környezetterheléssel járó súlyos baleseti eseménysort.

- A telephely olyan müszaki kialakítással rendelkezik (kármentő, duplafalú technológiai edényzet), amely garantálja a környezetre veszélyes anyagok környezetbe jutó

\footnotetext{
${ }^{5}$ A metanol kémiailag a legegyszerübb alkohol. Közönséges házi oldószer, tiszta, színtelen, jellegzetes szagú gyúlékony folyadék, vagy gőz, mely vízzel, más alkoholokkal és éterrel korlátlanul elegyíthető. Levegővel keveredve robbanó elegyet képezhet. A metanol méreg, mely az ideg- és keringési rendszert károsítja.
} 
mennyiségének korlátozását, valamint az erre vonatkozó szabályzók is rendelkezésre állnak,

- a kikerült környezetre veszélyes anyag összegyüjtését, mentesítését vagy más módon történő ártalmatlanítását lehetővé tevő eszközök és a leírását tartalmazó szabályzók rendelkezésre állnak,

- a környezeti kárelhárítási eljárások anyagi-technikai és személyi feltétele biztosított, valamint a telephely kárelhárító szervezete felkészült a környezeti kárelhárítási feladatok végzésére, a szükséges feladatokat terv szerint rendszeresen gyakoroltatja.

A környezetterheléssel járó súlyos balesetből származó veszélyeztetés elfogadható. A fentiek értelmében megállapítható, hogy a telephely megfelel a 219/2011. (X.20.) Korm. rendelet 7. mellékletének 1.7 pontjában taglalt feltételeknek. [14]

A katasztrófavédelem tevékenységére a súlyos események, veszélyhelyzetek időszakában fokozott társadalmi-, illetve politikai figyelem is irányul. Markánsan jelentkezett mindez 2010ben a tavaszi árvizeknél és a vörösiszap-katasztrófánál is. A borsodi árvíz, illetve maga a vörösiszap-katasztrófa azonban rávilágított arra, hogy hiányosságok voltak a megelőzés, a hatósági tevékenység, a beavatkozás, a közigazgatás és a társadalmi felkészítés terén. [15]

\section{Veszélyeztető hatások Pusztaederics településen}

Pusztaederics a Zalai dombság Bak-Gutorfölde-Lenti településeket összekötő közút és vasútvonal tengelyében, a Tómelléki-patak völgyében elterülő település, amelyet keletről, délről és nyugatról 250-300 m magas dombok határolják.

Régmúltra visszavezethető nemesi település, amelyben a mezőgazdálkodási tevékenységet primer szerepét nagymértékben befolyásolta a környező gyárak megépítése és üzemeltetése (Zalakerámia Zrt., Magyar Földgáztároló Zrt. Földalatti Gáztárolója), amelynek köszönhetően a megélhetés már nem az éves termésátlagtól függött, mivel a gyárak biztosították a környező településen élők bevételi forrását. Infrastruktúráját tekintve Pusztaederics zsáktelepülés.

A község kialakult utcahálózata, domborzati és vízrajzi adottságai, közlekedési rendszere kedvezőtlen szerkezetet eredményezett. A vasút, valamint a vasút mentén lévő alacsony, vizenyős terület a községet - északnyugati és délkeleti részre - kettévágja. A két településrészt csak egy utca köti össze. Az épületek épületszerkezetét tekintve többségük egyszintes lakóépület, amely a legutóbbi adatok szerint 96 lakóépületet és 4 középületet foglal magába.

A településszerkezetet kialakító domborzati viszonyok védtelenné teszik a falut az É-D-i irányból betörő nagy erejü szelek, viharok ellen. A települést vízrajzi szempontból két patak, a Tómelléki és a Berek patak befolyásolja: az északi irányba futó Tómelléki-patak a Balaton, míg a Berek patak a Mura vízgyújtőjéhez tartozik. Legnagyobb vízfolyása a Berek patak. Az itteni hajdani tó, pontosabban a völgy egy részét kitöltő mocsaras terület völgyi vízválasztó.

Az alapvető szolgáltatásokat tekintve a villamos áram és a vízszolgáltatás kiépítése 100 \%os, ugyanakkor, ha nem is teljeskörüen és egységesen, de a szennyvízszolgáltatás, vezetékes gázellátás is megoldott igény szerint a településen. Az infokommunikációs hálózatok (telefon, televízió, internet) kiépítettnek tekinthetök.

\section{Katasztrófavédelmi gyakorlat vizsgálata}

A pusztaedericsi gáztároló történetében 2012-ben tartották az első, több társhatóság bevonásával végrehajtott közös komplex gyakorlatot.

A tárolt veszélyes anyag mennyisége miatt vált kötelezővé a védelmi tervek elkészítése és az abban foglaltak gyakorlati keretek közötti ellenőrzése. A közös gyakorlat forgatókönyve szerint egy viszonylag rövid idő alatt történt káresemények sorozatára kell reagálnia a beavatkozó állománynak, mindenkinek a saját keretein belül, először az üzemben, a fejcsö- 
rendszernél történt gázkifúvás és begyulladás. Ennek felszámolására nem volt elegendő az üzemi személyzet, ezért a katasztrófavédelem segítségét kérték.

A helyzet komolyságára tekintettel, a Zala Megyei Katasztrófavédelmi Igazgatóság (Zala MKI) műveletirányító központja $\mathrm{V}$. kiemelt fokozattal ${ }^{6}$ a megye minden tűzoltóegységét riasztotta. A bajt tetézendő a következő esemény Pusztaedericsen következett be, ahol kútkarbantartás közben gáz szabadult ki, ami a lakosságot veszélyeztette. Mivel a gáz koncentrációja veszélyes szintet ért el, telefon, sziréna és autók használata nélkül kellett megoldani a településről harminc ember kimenekítését. Öket a szomszédos községek befogadó állomásain helyezték el.

A gyakorlat harmadik elemeként Tófej határában gázkút felújításkor a kitörésgátló hibája vezetett robbanáshoz, ami a közeli lakóépületet is megrongálta, az ott élők sérülését okozva. A romok alól kimentett embereket a tófeji iskolában berendezett egészségügyi ellátó helyre vitték. A gyakorlatot a katasztrófavédelem részéről jelenlévő gyakorlatvezető megfeleltre értékelte, amely remekül példázza az elméleti síkon kigondolt havária-helyzetek gyakorlati megvalósításának létjogosultságát, nagymértékben növelve az ott élők biztonságérzetét. [16] Megvizsgáltuk a MFGT Zrt. Pusztaederics Földalatti Gáztároló veszélyeztető hatásainak kezelésével kapcsolatos, Tófej és Pusztaederics község Külső Védelmi Tervét ${ }^{7}$. A terv egyértelmüen meghatározza a katasztrófavédelem önkormányzati és rendvédelmi feladatait:

- Riasztás és értesítés vétele a bekövetkezett eseményről, a helyzet tisztázása érdekében a felderítés, helyszíni szemle szervezése és végrehajtása.

- A tervekben elöírt tájékoztatások, kölcsönös értesítések végrehajtása.

- Javaslatok megfogalmazása a kialakult helyzet alapján a veszélyelhárítási, lakosságvédelmi, kárfelszámolási és ideiglenes helyreállítási feladatokra.

- A Külső Védelmi Tervben szereplő Hivatásos Tủzoltóságok, Katasztrófavédelmi Kirendeltség tevékenységének irányítása és koordinálása a Zala MKI igazgatója által kijelölt katasztrófavédelmi tiszt helyszínre rendelésével.

- A veszélyelhárítási - katasztrófavédelmi és kárfelszámolási feladatokat irányító települési polgári védelmi szervezetekbe, $\mathrm{HVB}^{8}$ Katasztrófavédelmi Munkacsoportjában és az MVB $^{9}$ Operatív Munkacsoportjában szakemberek biztosítása, az ott folyó munka során a szakmai elöírások és követelmények érvényesítése.

- Kezdeményezni a veszélykörzetből kimenekített lakosság ideiglenes elhelyezését, javaslatot tenni a befogadási helyekre, közremüködni az ezzel kapcsolatos okmányok kidolgozásában és a feladat végrehajtásának koordinálásában.

- Közremüködés a helyszíni veszélyelhárítási és kárfelszámolási feladatok végrehajtásához szükséges hiányzó eszközök, felszerelések és anyagok biztosításában.

- Közremüködés a veszélykörzetből kimenekített lakosság szállítási, ideiglenes elhelyezési és ellátási feladatainak szervezésében, végrehajtásában, az ahhoz

\footnotetext{
${ }^{6}$ V-ös riasztási fokozatról akkor beszélünk, ha a beavatkozáshoz 6-nál több raj szükséges.

${ }^{7}$ A veszélyes anyagokkal foglalkozó üzem biztonsági jelentésében vagy a hatóság döntése alapján a biztonsági elemzésében vagy a súlyos káresemény elhárítási tervben bemutatott veszélyeztető hatások elleni védekezés érdekében a veszélyeztetett településeken külső védelmi tervet kell készíteni a biztonsági dokumentáció elfogadását követő 6 hónapon belül.

${ }^{8}$ Helyi Védelmi Bizottság: A helyi védelmi bizottságok létrehozását az motiválta, hogy a sok település, illetve fóvárosi kerületek irányítása egy centrumból megoldhatatlan feladatot jelentene. A helyi védelmi bizottság illetékességi területét a kistérségi igazgatás rendszerének, valamint az érintett polgármesterek véleményének figyelembevételével a megyei védelmi bizottság állapítja meg.

${ }^{9}$ Megyei Védelmi Bizottság: irányítja a helyi védelmi bizottságok honvédelmi tevékenységét, irányítja a polgármesterek honvédelmi tevékenységét, ellátja a hatáskörébe utalt, a különleges jogrend időszakában végrehajtandó polgári védelmi feladatokat, biztosítja a védelmi igazgatási szervek müködésének feltételeit, és irányítja a rendkívüli intézkedésekkel hatáskörébe utalt feladatok végrehajtását.
} 
szükséges, megyei katasztrófavédelmi raktárban meglévő anyagok biztosításában, a hiányzó anyagok beszerzésében.

- A veszélyelhárítási és kárfelszámolási feladatok eredményes végrehajtása érdekében a közremüködő szervek tevékenységének koordinálása, még szükséges erők eszközök, szolgáltatások alkalmazásának, biztosításának kezdeményezése.

- Szükség esetén javaslatot tesz, és közremüködik az áldozatokkal kapcsolatos feladatok végrehajtásának szervezésében.

- Szakembert biztosít a keletkezett károk felméréséhez, védekezéssel kapcsolatos költségek elszámolási okmányainak elkészítéséhez, elvégzett munkák és szolgáltatások felméréséhez. [17]

Kiemelem a lakosság tájékoztatásához szükséges eszközrendszert:

1. Helyi rádió: Egerszeg Rádió Zalaegerszeg, Telefon: 92/31 ...., Fax: 92/31....

2. Helyi televízió: ZTV Kft. Zalaegerszeg, Telefon: 92/31.... Fax: $\quad 92 / 31 \ldots \ldots$.

3. Tófej Hörmann-Rema sziréna és tájékoztató eszköz

4. Hangosbeszélő gépkocsik: Tüzoltóságok, Rendőrkapitányság eszközei

5. Szórólapok,

6. Telefonok. [18]

\section{FÖLDALATTI GÁZTÁROLÓT ÉRINTŐ TÜZESET}

A MFGT Zrt. nagyhegyesi földalatti gáztároló üzemében technológiai meghibásodás következtében 2018. november 20-án tüz keletkezett. Fritsch László, a MFGT Zrt. elnökvezérigazgatója elmondta, hajnali három óra után vették észre a biztonsági szolgálat járőrei, hogy kifúvatás van a befutósoron. Valamikor négy óra után be is gyulladt, leválasztották a hibás vezetéket, ennek ellenére a csőben lévő gáz továbbra is 15 méteres lánggal égett. Az okot egyelöre nem tudják.

Az ország gázellátása biztosított, ugyanis a társaság másik három földgáztárolója - Zsana, Pusztaederics, Kardoskút - vette át a szolgáltatást. Emiatt a kereskedők földgázigényeit ki tudták elégíteni. A cég munkatársai folyamatos kapcsolatban voltak mind az országos földgázhálózat üzemeltetőjével, mind a földgázkereskedőkkel annak érdekében, hogy továbbra is zavartalan legyen az országos gázforgalom.

Nagyhegyes község közösségi oldalán közzétették a polgármester közleményét, melyben azt írta, az ipari baleset Nagyhegyes belterületét nem érinti; valamint életbe léptette a település Külső Védelmi Tervét. Arra kérték a lakókat, hogy a földgáztároló telephelyét ne közelítsék meg a külterületi alsó utakon sem. [19]

IV. fokozatú riasztás ${ }^{10}$ volt érvényben a környéken, amely a robbanásveszélyes miatt továbbra is le volt zárva. A szakemberek hütötték a balesetet okozó meghibásodott vezetéket, hogy megakadályozzák azt, hogy a gázzal teli tartályok berobbanjanak.

A Hajdú-Bihar megyei hivatásos és önkormányzati tüzoltók nyolc vízsugárral dolgoztak a tüz eloltásán és a terület lehütésén. 35 tüzoltó nyolc fecskendővel oltotta a lángokat. A katasztrófavédelmi mobillabor folyamatos méréseket végzett Nagyhegyes környékén. A mérések gáz jelenlétét nem mutatták ki a levegőben, ezért nem kellett kitelepíteni a lakosságot Nagyhegyesröl. A mentőszolgálat is a helyszínen tartózkodott, de senki nem sérült meg.

\footnotetext{
${ }^{10}$ IV-es riasztási fokozatról akkor beszélünk, ha a beavatkozáshoz 4,5-6 tüzoltó raj szükséges.
} 


\section{KÖVETKEZTETÉSEK}

A szerzők elemezték a katasztrófavédelem jogi eszközeinek segítségével az önkormányzati és rendvédelmi feladatok komplexvizsgálatát, kiemelten a szénhidrogén-felhasználáshoz kapcsolódó földalatti gáztárolás speciális esetét.

Elsőként megvizsgálták a földgáz, mint anyag keletkézének körülményeit, tulajdonságait, szállításának, felhasználásának majd tárolásának lehetőségeit. Fontos itt megjegyezni, hogy a magyarországi gázhálózat térfogata több mint 43 millió $\mathrm{m}^{3}$, ami egy kisebb gáztároló kapacitásával felér. ${ }^{11}$

Endrődi István és Teknős László korábbi cikkeikben rámutattak arra, hogy az infokommunikációs technológiák fejlődésével a lakosság tájékoztatásának lehetőségei kiszélesedtek. A társadalom átalakulásával egyre fontosabb szerepet tölt be a nyilvánosság. A közösségek információszerzése mára egyszerübbé, gyorsabbá vált. Míg a régi korokban az információ átadás-átvételben a tér és idő fontos szerepet játszott, ma már ezek a tényezők nem jelentenek gondot, mivel az internet a fizikai határokat túllépve lebontotta a kötöttség kereteit. Ennek a felgyorsult információáramlásnak az egyik releváns elemévé vált a közösségi média. [20][21][22][23]

A korábban átélt válságkezelések során [24], [25] arra az álláspontra jutottak a szerzők, hogy a kríziskommunikációs tervben szükséges a teendőket előre rögzíteni. Ilyenek a lakosság megnyugtatásának módjai, a kommunikációs irányelvek és a sajtókapcsolatok. Egy konkrét káresemény felszámolását követően nem csak a szakmai tevékenységet kell elemezni, hanem az esemény kezelésével kapcsolatos kommunikációt is. A végrehajtott feladatokat, valamint a jövőbeni hatások értékelését, elemzését is el kell végezni.

A tanulmányozott külső védelmi tervekben a lakosságtájékoztató eszközök jók, de korszerüsítésre, naprakésszé tételükre van szükség. Szerzők véleménye szerint mobiltelefonszámokat is tartalmaznia kell a médiával történő kapcsolattartásra. Fax kevés helyen üzemel, viszont rajzok, ábrák, képek továbbításra is alkalmas. A közösségi csatornák az idős emberek kivételével - szinte minden ember, felnőtt és gyermek okostelefonján megtalálhatók.

A katasztrófavédelem rendvédelmi feladatainak példáját az utolsó bekezdésben tárgyalt tüzeset hủen tükrözi, milyen az, amikor egy elgyakorolt (szimulált) gázkitörés valósággá válik. Jól látható, hogy a katasztrófavédelem, az önkormányzat és társszervek nélkül egy különleges helyzetet nehéz kivédeni.

A nagyhegyesi káreset során a polgármester által elrendelt lakosságvédelmi intézkedésre is sor került, a polgármester asszony a XXI. század infokommunikációs csatornáit kihasználva az interneten két hivatalos tájékoztatót is közzé téve szólt a településen élőkhöz, tájékoztatva őket először az elrendelt korlátozó intézkedésekről, majd a második esetben a veszély elhárításáról és a helyzet normalizálódásáról.

\section{ELHASZNÁLT IRODALOM}

[1] 219/2011. (X. 20.) Korm. rendelet a veszélyes anyagokkal kapcsolatos súlyos balesetek elleni védekezésröl

[2] ERDÉLYI L., NÉMETH GY.NÉ.: A föld alatti gáztárolók növekvő szerepe a gázigények kielégitésében Magyarországon; http://www.ombkenet.hu/bkl/koolaj/2003/bklkoolaj 2003_1112_01.pdf (letöltve: 2019.02.06.)

\footnotetext{
${ }^{11}$ A magyar gázhálózat hosszának $450000 \mathrm{Km}$ és átlagolt névleges átmérőjének, $350 \mathrm{~mm}$ a szorzata (r2 $\left.\pi^{*} \mathrm{~m}\right)$

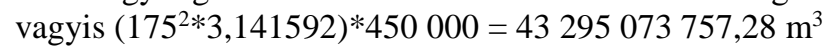


[3] TIGÁZ-DSO Földgázelosztó Kft.: Földgázkészletek; http://www.mindentafoldgazrol.hu/ ellatasbiztonsag/foldgazkeszletek (letöltve: 2019.02.06.)

[4] PTE Fizikai Intézet: Környezetfizika I. 9. Földgáztermelés, felhasználás fizikája; 2011 12, $N B$ http://www.physics.ttk.pte.hu/pages/munkatarsak/nemetb/KorFiz-I-9-foldgaz.pdf (letöltve: 2019.02.06.)

[5] FÖLDGÁZ, A környezetkímélő Energia Forrása: Termelés; www.foldgaz.hu/huHU/Amit_a_foldgazrol_tudni_kell/A_foldgaz_utja/Termeles (letöltve: 2019.02.06.)

[6] Gázvezetékek hálózata Magyarországon (2013) http://www.terport.hu/tematikusterkepek/gazvezetekek-halozata-magyarorszagon-2013 (letöltve: 2019.02.07.)

[7] MAGYAR FÖLDGÁZTÁROLÓ ZRT.: Föoldal, Tevékenységünk, Földgáztárolók; www.magyarfoldgaztarolo.hu/hu-HU/Tevekenysegunk/Gaztarolok 2019.02.07.)

[8] DEÁKNÉ K.: Energiahordozók és -források; https://slideplayer.hu/slide/2191965/ (letöltve: 2019.02.07.)

[9] FRITSCH L.: A földgalatti gáztárolók szerepe a gázellátó rendszerben; http://www.dunagaz.hu/UserFiles/File/konf2015/Fritsch_Laszlo_prezentacio.pdf (letöltve: 2019.02.07.)

[10] GAS INFRASTRUCTURE EUROPE: GIE Storage Map; https://www.gie.eu/index.php/ gie-publications/maps-data/gse-storage-map (letöltve: 2019.02.08.)

[11] TÖZSDEFÓRUM: Gyorsan töltődnek az európai gáztárolók; https://www.tozsdeforum.hu /uzlet/gazdasag/gyorsan-toltodnek-az-europai-gaztarolok37547.html (letöltve: 2019.02.09)

[12] MAGYAR FÖLDGÁZTÁROLÓ ZRT.: A Magyar Földgáztároló Zrt. magyarországi földalatti gáztárolói; $\quad$ www.magyarfoldgaztarolo.hu/ huHU/Tevekenysegunk/Gaztarolok (letöltve: 2019.02.09.)

[13] MAGYAR FÖLDGÁZTÁROLÓ ZRT.: Pusztaedericsi Gáztároló Biztonsági Jelentése; http://www.tofej.hu/wp-content/2016/06/PED-BJ-kivonat-20160601.pdf $\quad$ (letöltve: 2019.02.09.)

[14] 234/2011. (XI. 10.) Kormányrendelet a katasztrófavédelemről és a hozzá kapcsolódó egyes törvények módositásáról szóló 2011. évi CXXVIII. törvény végrehajtásáról

[15] MUHORAY Á.: A katasztrófavédelem aktuális feladatai; Hadtudomány (online) 3-4: 2012. pp. 1-17. ISSN 1588-0605 http://mhtt.eu/2012/2012 elektronikus/2012 e Muhoray Arpad.pdf (letöltve: 2019.02.09.)

[16] ARANY G.: Ha kitör a nagynyomású gáz a földalatti tárolóból; https://www.zaol.hu/ cimlapon/ha-kitor-a-nagynyomasu-gaz-a-foldalatti-tarolobol-fotokkal-1440802/ (Letöltés: 2019.02.12.)

[17] Külső Védelmi Terv Tófej KVT_Tófej-2018.doc

[18] Külső Védelmi Terv Pusztaederics_KVT_Pusztaederics-2018.doc

[19] FACEBOOK.COM: Nagyhegyes Község: I és II. Hivatalos lakosságtájékoztató; https://www.facebook.com/190062794456914/photos/a.234712843325242/1778391708 957340/?type $=3 \&$ theater (letöltve: 2019.02 .12 .)

[20] ENDRŐDI I: Polgári védelmi tudományos problémák kutatási eredményeinek összefoglalás; NKE, Budapest, 2015. 8. 1. ISBN 978-615-5057-44-1 http://m.ludita.uni- 
nke.hu/repozitorium/bitstream/handle/11410/9936/Endrödi\%20kézikönyv.pdf?sequence =1\&isAllowed=y (letöltve: 2019.02 .16 .)

[21] TEKNÖS L: THE COMPLEXITY AND METHODS OF CITIZEN EMERGENCY PREPAREDNESS; HADMÉRNÖK, XIII. Évfolyam 3. szám - 2018. szeptember. pp. 306-325. (2018) HU ISSN 1788-1919. http://www.hadmernok.hu/183 23 teknos.pdf?fbclid=IwAR3Z7WwPnw7Z8Lbb66KJQiJJWNQOVcIntxaPT Wo1chlGpPfvefjE8TO-7JfU (letöltve: 2019.02.20.)

[22] TEKNÖS L: EXPLORING THE POSSIBILITIES OF CITIZEN PREPARATION FOR EXTREME WEATHER EVENTS - AN INTERNATIONAL OUTLOOK; HADMÉRNÖK, XIII. Évfolyam 4. szám - 2018. december. pp. 241-260. HU ISSN 1788-1919. http://www.hadmernok.hu/184_19 teknos.pdf?fbclid=IwAR1gNvKb6L6txZQOBaWZGwmghCXon3vKDOExU23QE8I33gBaTVAcKlwvn4 (letöltve: 2019.02.20.)

[23] TEKNÖS L., ENDRÖDI I.: New possibilities of emergency communication and information in the protection phase of disaster management. AARMS, Vol. 13, No. 2 (2014). pp. 235-249., HU ISSN 2498-5392. https://folyoiratok.uni-nke.hu/document/uninke-hu/aarms-2014-2-teknos.original.pdf (letöltve: 2019.02.20.)

[24] TÓTH A.: Az első régiós irányítótörzs kríziskommunikációja a tapasztalatok tükrében; BOLYAI SZEMLE XXVI. évfolyam: 1. szám pp. 86-95 (2017) https://www.uninke.hu/document/uni-nke-hu/Bolyai_Szemle_2017_01_web.pdf (letöltve: 2019.02.20.)

[25] TÓTH A.: A bitumenfeldolgozás során történt tartályrobbanások és tüzesetek vizsgálata - I. rész; HADMÉRNÖK XIII. évfolyam 1. szám - 2018. március pp. 217-229. http://hadmernok.hu/181_17_toth.pdf (letöltve: 2019.02.20.) 